\title{
Todorov, Tzvetan. Leer y vivir. Barcelona: Galaxia Gutenberg, 2018. 316 pp.
}

\author{
Angélica Aguillon Lombana ${ }^{1}$
}

$L$ eer y vivir es un libro en el que se coleccionan, de manera póstuma, ensayos, reseñas y artículos escritos en diferentes etapas de la prolífica vida intelectual de este pensador búlgaro-francés. Tales textos tienen que ver con diversos temas y autores que contribuyeron con su formación en campos como la historia, la memoria, el arte, la filosofía del lenguaje, las ciencias sociales, entre otros. Todos ellos asumidos por Todorov como elementos necesarios para entender el desarrollo de aspectos como la cultura y el pensamiento ilustrado en el individuo, pero también dentro de los grupos sociales.

La obra está compuesta por tres partes, a través de las cuales el autor resuelve un planteamiento central: la lectura es el principal elemento que propende hacia la posibilidad humana de entendimiento, y, por tanto, garantiza el acceso a la autonomía de los individuos y a la emancipación de los pueblos. Para ello, se hace necesaria una reflexión situada en la humanidad misma de cada sujeto en relación con las actuaciones de la otredad. Así, leer de forma humanizante implica situarse en las distintas realidades a través de diversos tipos de textos que faciliten la interpretación de las múltiples aristas que componen la sorprendente complejidad humana. Por lo tanto, la lectura del mundo que se hace en piezas musicales, de teatro, de danza, y por supuesto, de la literatura, alimenta el espíritu y beneficia procesos de comprensión de forma reflexiva y profunda.

Pero el autor de obras como Los enemigos íntimos de la democracia, Nosotros y los otros, Los abusos de la memoria, Simbolismo e interpretación, El nuevo desorden mundial, por mencionar solo unas cuantas del gran compendio que le dejó a la humanidad, no solo se centra en analizar diversas obras de arte que considera de valor estético e intelectual, sino que revisa el papel de los productores de dichas obras, como también de escritores de textos de orden más academicista. De hecho, para instaurar sus disertaciones en torno a temas relacionados con la moral, el papel de la religión, de la historia, de la memoria, y otros, se basa en el análisis de discursos ofrecidos por algunos personajes de la vida pública, a quienes las masas casi siempre siguen sin cuestionar.

1 Magíster en Lingüística aplicada del español como lengua extranjera por la Pontificia Universidad Javeriana de Bogotá, Colombia. Docente e investigadora de lenguas extranjeras de la Universidad Antonio Nariño, Colombia. Correo electrónico: aaguillon@uan.edu.co 
De tal manera que Todorov concede un papel trascendente en el desarrollo de las sociedades actuales tanto a los intelectuales como a los sistemas educativos. Al respecto plantea que estos últimos deben revisarse en tanto están formando ciudadanos acríticos, y, por lo tanto, carentes del valor de la rebeldía que les provea estrategias para actuar de forma contestaria frente a diversos órdenes del poder. En relación con el papel de los intelectuales, el autor afirma que su principal objetivo debe ser perseguir la libertad no solo para alimentar su espíritu, sino para darla a conocer a quienes los toman como ejemplo. Ello implica indudablemente armarse de coraje, puesto que ir en contra de los poderes hegemónicos que solo propenden por el bien propio, siempre implicará algún peligro para el bienestar de quien decida involucrarse en los imperativos éticos que ello implica.

El libro se compone de tres apartados: Vivir juntos; Leer, escuchar y ver, y finalmente el apartado denominado Saber. En el primero de ellos, se agrupan textos en los que el autor reflexiona sobre las implicaciones de la vida con y desde la otredad. Así, se compilan una serie de escritos relacionados con cuestiones como la moral; la religión y la política; la identidad de los pueblos y el derecho del ciudadano a la desobediencia; la pluralidad humana y la era de la tecnología; implicaciones de los procesos de memoria en la construcción del presente; las versiones de los actores que participan en las guerras y las formas como legitiman el poder, entre otros asuntos.

Si bien todos los temas presentados en este apartado pueden resultar de interés para cualquier humanista, llaman la atención sus apreciaciones sobre el tipo de lectura que debe incentivarse en la era de la tecnología. Así, propone situarse críticamente frente a falacias como que la masificación de la información trae consigo la instauración de verdaderos sistemas democráticos. Al respecto afirma que la sobreabundancia de información puede resultar perjudicial si no está mediada por una función formativa que persiga el análisis situado de la información que circula por la web.

Lo anterior involucra el reconocimiento de un otro productor y, a la vez, receptor de ideas, caracterizado por una ontogénesis propia que siempre debe ser tenida en cuenta a la hora de emplazarse y actuar en el mundo. Ello implica pensar en que la dificultad que no facilita la generación de verdaderos procesos democráticos y de construcción social humanizada y humanizante, tiene que ver con el no reconocimiento de ese otro, con la no asunción de un sujeto que debe hacerse responsable de sus actos, pero también que debe ser tenido en cuenta en tanto productor de enunciados simbólicos que dotan de sentido a su mundo y al mundo de los otros.

El segundo aparatado denominado Leer, escuchar y ver, está dedicado a textos que Todorov escribió en relación con lo que implican estos sentidos en los procesos de apropiación y discernimiento de información proveniente de diversos contextos geográficos y temporales en los que se han constituido los distintos grupos humanos. Los escritos que el lector encontrará en esta sección del libro, se centran en resaltar el valor que posee la literatura, especialmente la novela, en la reconstrucción y deconstrucción histórica de la vida humana.

$\mathrm{Al}$ respecto, se rescatan ideas en relación con dos niveles de lectura que se dan en la obra de arte y que vale la pena distinguir: uno que está vinculado con una forma intuitiva, meramente relacionado con la experiencia existencial en la que tiene cabida cualquier consideración de tipo subjetivo, y otro que ocurre en perspectiva de conocer mejor el universo de la obra de arte y de la realidad que representa. En este apartado se dedican varios textos a la revisión de la importancia de la novela en tanto elemento proveedor de un conocimiento al que solo se puede acceder por este medio, puesto que la novela es el 
género que, por excelencia, concentra aspectos centrales de los enigmas existenciales de la raza humana de manera completa.

En esta parte del libro también se agrupan escritos relacionados con el análisis del teatro, la ópera, la pintura como elementos que son útiles en la interpretación del mundo a través de códigos que superan lo lingüístico, y sentidos que superan lo visual, pero que se siguen manteniendo en la línea de artefactos que trasmiten elementos propios de la ontogénesis humana en diversos contextos. A través de dichos escritos, se intuye la idea de que la lectura hecha en objetos artísticos que se distancian de la construcción meramente lingüística, no impone significados exactos, sino que dispone para la sensibilidad y la divergencia en la construcción de sentido.

Con respecto a ello, se propone que la sobreabundancia de imágenes fílmicas y fotográficas provee la transmisión de mensajes contundentes siempre y cuando estas se lean de forma contextualizada, puesto que ellas evocan la intensidad de una realidad, pero a diferencia del texto escrito, no plantean ideas concretas por sí mismas. De igual forma, es importante resaltar que en sus escritos Todorov asume que los artistas no solo construyen la obra con lo que saben, sino con lo que son, por tanto, la lectura que toma como texto la pieza artística es existencialmente impactante y esencialmente compleja.

En la última parte del libro, si bien es la más corta, no deja de ser significativa, se agrupan textos en los que el autor propone un recorrido por los principales aportes que han realizado eruditos como Germain Tillion, Lévi-Strauss, Joseph Frank, Emily Benveniste y otros. Reconociendo que las ciencias humanas deben asumir que el ideal matemático es la mejor manera de borrar los vestigios de subjetividad que aún las ronda. Ello sin dejar de criticar políticas estatales que se preocupan por cuantificarlo todo, que solo buscan la construcción de conocimiento de forma colectiva y sistematizada pero a su manera.

Esto, aunque deja claro que las zonas de sombra que rodean el conocimiento humanístico, se corresponden con la profunda complejidad que compone a seres sentipensantes que se mueven y transforman en el tiempo y el espacio. Por tanto, rechaza todo tipo de totalitarismo en tanto estos clasifican a los seres humanos en buenos o malos sin dejar opción al elemento circunstancial de la vida. Al respecto afirma: "Una sociedad solo existe en el movimiento y en los encuentros. Su identidad es fruto cambiante de esta dinámica”. P, 64.

Ya para terminar, es importante plantear que esta obra póstuma de Todorov puede convertirse en un elemento de gran utilidad tanto para quienes se declaren seguidores de sus ideas en alguno de los campos disciplinares en los que incursionó a lo largo de su trayectoria como intelectual, como para quienes deseen iniciarse en el conocimiento de las ideas de uno de los más grandes pensadores del siglo XX. Para los primeros, puesto que se recogen, a manera de síntesis, ideas ampliamente desplegadas en textos publicados previamente. Para los segundos, el libro puede resultar una entrada atrayente que facilita la incursión en el fascinante mundo de las ideas todorovianas, siempre concebidas con rigor y expuestas con sencillez y pulcritud. 